\title{
Control of huisache and honey mesquite with a carpeted roller herbicide applicator
}

\author{
RODNEY W. BOVEY AND ROBERT E. MEYER
}

\section{Abstract}

Several herbicides were evaluated for control of honey mesquite (Prosopis glandulosa Torr.) and huisache [A cacia farnesiana (L.) Willd.] using a tractor-mounted carpeted roller. Foliar sprays of picloram $+2,4,5-T$ at $0.28+0.28$ and $0.56+0.56 \mathrm{~kg} / \mathrm{ha}$ were included for comparison. When applied by carpeted roller, picloram at $60 \mathrm{~g} / \mathrm{L}$ killed about $40 \%$ of the honey mesquite plants whereas $120 \mathrm{~g} / \mathrm{L}$ killed 63 to $83 \%$ of the plants after 2 years. Clopyralid at 60 or $120 \mathrm{~g} / \mathrm{L}$ killed $65 \%$ or more of the plants. Mixtures of picloram + clopyralid (1:1) at $30+30 \mathrm{~g} / \mathrm{L}$ killed 53 to $73 \%$, whereas, $60+60 \mathrm{~g} / \mathrm{L}$ killed 83 to $98 \%$ of the honey mesquite. Clopyralid + triclopyr (1:1) $30+30 \mathrm{~g} / \mathrm{L}$ killed 48 to $58 \%$ of the plants, while $60+60 \mathrm{~g} / \mathrm{L}$ killed 80 to $85 \%$. Picloram + 2,4,5-T (1:1) applied by the carpeted roller was usually more effective than foliar sprays of picloram + 2,4,5-T. For huisache, picloram, clopyralid, or picloram + clopyalid at a total of 60 or $120 \mathrm{~g} / \mathrm{L}$ killed $60 \%$ or more of the plants after 1 year. Picloram + clopyralid at $60+60 \mathrm{~g} / \mathrm{L}$ applied in 1983 and 1984 killed $92 \%$ or more of the huisache. Picloram + 2,4,5-T at $60+60 \mathrm{~g} / \mathrm{L}$ killed 73 to $83 \%$, but foliar sprays of picloram + 2,4,5-T were sometimes inefiectve. Glyphosate, dicamba, triclopyr and 2,4,5-T applied alone reduced the canopy of honey mesquite and huisache but usually killed few plants. Honey mesquite was controlled from spring applications, whereas, summer and fall treatments controlled huisache.

Key Words: picloram, clopyralid, triclopyr, dicamba, glyphosate, 2,4,5-T, canopy reduction, mortality

Herbicide foliar sprays are usually superior to soil treatments for control of honey mesquite (Prosopis glandulosa Torr.) and huisache [Acacia farnesiana (L.) Willd.] (Bovey and Meyer 1978, Bovey and Meyer 1981). Since these species sometimes occur on grazing lands in crop areas, foliar sprays of herbicide cannot be used because of possible damage from spray drift. These species are also rapid and persistent invaders of improved pastures such as bermudagrass [((Cynodon dactylon L.) Pers.], and herbicide foliar sprays on the forage may be undesirable because of injury or herbicide residues.

A carpeted roller for conrol of small shrubs and honey mesquite has been developed (Mayeux and Crane 1984, 1985). The roller consisted of a polyvinyl chloride (PVC) cylinder covered with common household carpet. Acceptable control of honey mesquite was obtained with picloram (4-amino-3,5,6-trichloro-2-pyridinecarboxylic acid) or clopyralid (3,6-dichloro-2-pyridinecarboxylic acid) when wiped onto the foliage under favorable growing conditions. Solutions containing $120 \mathrm{~g} / \mathrm{L}$ of herbicide were sometmes only slightly more effective than solutions containing $30 \mathrm{~g} / \mathrm{L}$ active ingredient of herbicides. In dense stands of honey mesquite, Mayeux (1987a) found that picloram, but not 2,4,5-T [(2,4,5-trichlorophenoxy)acetic acid], was effective at $60 \mathrm{~g} / \mathrm{L}$ from August

\footnotetext{
Authors are research agronomist and plant physiologist (retired), USDA-ARS, Southern Crops Research Laboratory, Pest Management Research Unit. Address: Dept. Range Science, Texas A\&M Univ., College Station, Texas 77843.

Contribution from the USDA, Agr., Res. Serv., in cooperation with the Texas Agr. Exp. Sta., College Station.

Mention of trademark name of proprietary product does not constitute a guarantee or warranty of the product by the USDA and does not imply its approval to the exclusion of other products that may also be suitable.

Manuscript accepted 13 February 1989.
}

and September treatments as well as June applications. Clopyralid or clopyralid + picloram was also effective in spring or fall. In honey mesquite, rates of application of herbicide applied with the carpeted roller at concentrations of 30,60 , and $120 \mathrm{~g} / \mathrm{L}$ averaged about $0.2,0.6$ and $1.25 \mathrm{~kg}$ ae/ha, respectively (Mayeux 1987b). Height of plants had no influence on volume of solution applied, but volume required to treat a given area increased with mesquite density. Active ingredient of herbicide applied to individual plants ( 0.3 to $3 \mathrm{~g} /$ shrub) decreased in a curvilinear manner with increasing stand density, suggesting that the carpeted roller is most effective in treating sparse stands. Waddington and Bittman (1987) attempted to control dense regrowth of aspen poplar (Populus tremuloides Michx.) and willows (Salix spp.) by passing a roller applicator several times in different directions using 2,4-D [(2,4 dichlorophenoxy)acetic acid], 2,4-D + picloram or glyphosate [ $N$ (phosphonomethyl)glycine]. Control of regrowth was in proportion to the number of passes made.

Information concerning the use of the carpeted roller to control huisache is limited. Preliminary data from greenhouse-grown plants indicated that picloram and clopyralid were more effective than triclopyr [(3,5,6-trichloro-2-pyridinyl)oxy]acetic acid or dicamba (3,6-dichloro-2-methyoxybenzoic acid) (Bovey et al. 1981) and that the use of a surfactant $(0.5 \% \mathrm{v} / \mathrm{v})$ in the treating solution significantly increased canopy reduction and mortality, especially at lower concentrations of herbicide (Mayeux and Bovey 1988). Scifres et al. (1988) recently indicated that picloram, clopyralid and equal-ratio mixtures of these herbicides reduced the live canopy of huisache by $90 \%$ or more by 2 years after treatment, but the least concentration that provided acceptable control was not indicated. None of the investigations mentioned compared a standard herbicide foliar treatment with the carpeted roller applicator.

The primary objective of this study was to evaluate the effectiveness of the carpeted roller applicator with a standard foliar herbicide application for control of honey mesquite and huisache, to identify effective herbicides and rates for acceptable control, and to evaluate certain herbicide mixtures and carriers in east central Texas. Summer and fall applications were also made on huisache to determine if fall application could be used to control huisache.

\section{Materials and Methods}

Dense stands of honey mesquite or huisache 1 to $2 \mathrm{~m}$ tall were treated. Multistemmed honey mesquite occurred on a Wilson clay loam (Vertic Ochraqualfs) while huisache occurred on a Bleiblerville clay (Udic Pellusterts) near Bryan and Washington, Texas, respectively. The plants consisted of vigorous regrowth from mechanical brush control several years before. Herbicides applied were the isopropylamine salt of glyphosate, the dimethylamine salt of dicamba, the propylene glycol butyl ether ester of 2,4,5-T, the butoxyethyl ester of triclopyr, the potassium salt of picloram, the triisopropanolamine salt of picloram + the propylene glycol butyl ether ester of 2,4,5-T (1:1), the monoethanolamine salt of clopyralid, the ethyl ester of benazolin (4-chloro-2-oxo-3(2H)-benzothiazoleacetic acid), and certain combinations of these formulations.

Herbicides were applied at total concentrations of 60 or $120 \mathrm{~g} / \mathrm{L}$, 
unless stated otherwise, with a carpeted roller mounted in place of a bulldozer blade on the front of a small tracklayer tractor. The roller was a $2.4-\mathrm{m}$-long by $21-\mathrm{cm}$-diameter aluminum cylinder rotated at $45-50 \mathrm{rpm}$ by a hydraulic motor in reverse direction of the forward motion of the tractor. Rotating the roller maximized application of herbicide on brush and minimized dripping. Herbicide solutions were supplied to the roller from a spray boom and spraying system on the tractor. Nine Teejet flat fan nozzles, Tip No. 9505 (Spraying Systems Co., North Ave., Wheaton, Ill. 60188 ), spread $27 \mathrm{~cm}$ apart and $29 \mathrm{~cm}$ above the roller were activated periodically to keep the carpet saturated. The roller was covered with common household nylon carpet with a dense mat of medium nap length. The carpet was secured to the roller by either steel bands or rubber stretch bands.

Height of the roller could be adjusted hydraulically during operation depending upon the height of the brush. Generally the roller was operated about 30 to $60 \mathrm{~cm}$ above ground, bending the plants over to maximize herbicide wiping. Different carpets were marked and attached for each herbicide or herbicide mixture. A standard spray treatment was included for comparison. Sprays of picloram $+2,4,5-\mathrm{T}$ in 1:1 ratio mixture was applied at a total of 0.56 or 1.1 $\mathrm{kg} / \mathrm{ha}$ in $187 \mathrm{~L} /$ ha of water with either a compressed air, handcarried, 3 nozzle boom sprayer or a 9 nozzle tractor mounted sprayer. Sprays were applied at the same time as the carpeted roller treatments.

Herbicides were applied to honey mesquite on 6 July 1983, 15 June 1984, and 12 June 1985 . Treatments on huisache were made on 26 July and 7 December 1982, 20 October 1983, 15 July 1985, and 14 July 1986. All experiments were randomized complete block designs with 2 replications. Plot size was 15 by $45 \mathrm{~m}$. Treatments were evaluated by visually estimating percent canopy reduction and mortality of 20 plants in each replicate 1 to 2 years after treatment. Plants with $100 \%$ canopy reduction and no live tissue or resprouts were considered dead. Data were subjected to analysis of variance, and means were compared by the least significant difference at the $5 \%$ level. Data were also analyzed as arcsinetransformed values (Steel and Torrie 1980), but there was no meaningful difference between the 2 analyses.

\section{Results and Discussion}

\section{Huisache}

Glyphosate, dicamba, triclopyr, and 2,4-5-T were essentially ineffective for killing huisache when applied either in July or December 1982 (Table 1). Herbicide 2,4,5-T at $240 \mathrm{~g} / \mathrm{L}$ killed 38\%

Table 1. Response of huisache near Washington, Texas, to herbicides by 2 August 1983 after application by a carpeted roller on two dates in 1982.

\begin{tabular}{|c|c|c|c|c|c|}
\hline \multirow[b]{3}{*}{ Herbicide(s) } & \multirow[b]{3}{*}{ Rate } & \multicolumn{4}{|c|}{ Date applied } \\
\hline & & \multicolumn{2}{|c|}{26 July 1982} & \multicolumn{2}{|c|}{7 December 1982} \\
\hline & & $\begin{array}{l}\text { Canopy } \\
\text { reduction }\end{array}$ & $\begin{array}{l}\text { Dead } \\
\text { plants }\end{array}$ & $\begin{array}{l}\text { Canopy } \\
\text { reduction }\end{array}$ & $\begin{array}{l}\text { Dead } \\
\text { plants }\end{array}$ \\
\hline \multirow[b]{2}{*}{ Glyphosate } & (g/L a.e.) & & & & \\
\hline & 180 & 32 & 5 & 40 & 0 \\
\hline Dicamba & 240 & 29 & 0 & 34 & 2 \\
\hline Triclopyr & 240 & 57 & 25 & 52 & 5 \\
\hline $2,4,5-\mathrm{T}$ & 240 & 60 & 10 & 74 & 38 \\
\hline Picloram & 120 & 84 & 60 & 92 & 80 \\
\hline $\begin{array}{l}\text { Picloram+ } \\
2,4,5-T\end{array}$ & $60+60$ & 84 & 75 & 92 & 78 \\
\hline $\begin{array}{l}\text { Picloram } \\
2,4,5-T\end{array}$ & $\begin{array}{l}0.56+0.56^{1} \\
\mathrm{~kg} / \mathrm{ha}\end{array}$ & 83 & 60 & 8 & 0 \\
\hline \multirow{2}{*}{\multicolumn{5}{|c|}{$\begin{array}{l}\text { Untreated } \\
\qquad \text { LSD }(5 \%) \text { for canopy reduction }=22 ; \text { for dead plants }=32\end{array}$}} & 0 \\
\hline & & & & & \\
\hline
\end{tabular}

IApplied by hand boom sprayer.
Table 2. Rainfall 1 or 2 months before or after herbicide treatment near the experimental sites. ${ }^{1}$

\begin{tabular}{|c|c|c|c|c|c|}
\hline \multirow[b]{3}{*}{ Species } & \multicolumn{4}{|c|}{ Months } & \multirow{3}{*}{$\begin{array}{l}\text { Total for year } \\
\text { and departure } \\
\text { from the long } \\
\text { term mean }\end{array}$} \\
\hline & \multicolumn{2}{|c|}{ Before } & \multicolumn{2}{|c|}{ After } & \\
\hline & 1 & 2 & 1 & 2 & \\
\hline \multicolumn{6}{|l|}{ Huisache } \\
\hline $26 \mathrm{Jul} 1982$ & 5.3 & 7.7 & 1.4 & 5.7 & $\begin{array}{l}93.5 \\
-6.7\end{array}$ \\
\hline 7 Dec 1982 & 14.3 & 33.6 & 5.8 & 14.8 & $\begin{array}{r}93.5 \\
-6.7\end{array}$ \\
\hline 20 Oct 1983 & 6.2 & 13.7 & 8.5 & 18.2 & $\begin{array}{r}137.9 \\
38.0\end{array}$ \\
\hline 15 Jul 1985 & 12.0 & 14.3 & 6.3 & 3.8 & $\begin{array}{r}103.6 \\
3.7\end{array}$ \\
\hline 14 July 1986 & 2.6 & 22.2 & 1.7 & 15.4 & $\begin{array}{r}109.4 \\
9.5\end{array}$ \\
\hline \multicolumn{6}{|c|}{ Honey mesquite } \\
\hline $6 \mathrm{Jul} 1983$ & 6.8 & 35.8 & 5.5 & 19.5 & $\begin{array}{r}122.3 \\
23.1\end{array}$ \\
\hline 15 Jun 1984 & 18.4 & 18.4 & 6.3 & 12.8 & $\begin{array}{l}97.6 \\
-1.7\end{array}$ \\
\hline 12 Jun 1985 & 4.8 & 15.1 & 7.4 & 13.2 & $\begin{array}{l}96.9 \\
-2.4\end{array}$ \\
\hline
\end{tabular}

'Rainfall amounts from Climatological Data, U.S. Dep. Commerce Nat. Climatic Center, Fed Bidg., Asheville, NC, as collected at Washington, Texas (huisache) and at College Station, Texas (honey mesquite).

of the plants in the December application, but picloram at $120 \mathrm{~g} / \mathrm{L}$ or picloram $+2,4,5-\mathrm{T}$ at $60+60 \mathrm{~g} / \mathrm{L}$ killed $78 \%$ or more of the plants. Picloram and picloram $+2,4,5-T$ killed 60 to $80 \%$ of the plants from June and December applications. Foliar sprays of picloram $+2,4,5-\mathrm{T}$ at $0.56+0.56 \mathrm{~kg} /$ ha killed $60 \%$ of the huisache plants in the July application but killed no plants when applied in December 1982. Possibly the huisache was approaching dormancy in December since extensive natural defoliation had occurred before treatment, and fewer leaves were available for herbicide absorption from foliar sprays than in July. Rainfall, however, was more favorable before and after treatment in December than July 1982 (Table 2).

Foliar sprays of picloram $+2,4,5-\mathrm{T}$ at $0.56+0.56 \mathrm{~kg} /$ ha were effective when applied in October 1983, reducing the canopy by $90 \%$ and killing $82 \%$ of the huisache (Table 3 ). Sprays of picloram + $2,4,5-\mathrm{T}$ at $0.28+0.28 \mathrm{~kg} /$ ha only reduced the canopy $60 \%$ and killed $48 \%$ of the huisache. Carpeted roller treatments that reduced the canopy by $92 \%$ or more and killed more than $88 \%$ of the plants included clopyralid and picloram + clopyralid at a total of 60 and $120 \mathrm{~g} / \mathrm{L}$ herbicide.

Picloram + clopyalid at $30+30 \mathrm{~g} / \mathrm{L}+20 \mathrm{~g} / \mathrm{L}$ benazolin was no more effective than picloram + clopyralid alone at the same rate (Table 3). However, picloram +2,4,5-T at 30+30 g/L in a 1:4(v/v) diesel oil:water carrier was as effective as picloram $+2,4,5-\mathrm{T}$ at $60+$ $60 \mathrm{~g} / \mathrm{L}$ in water carrier. Picloram alone at 60 and $120 \mathrm{~g} / \mathrm{L}$ killed 75 and $82 \%$ of the plants, respectively. Glyphosate, dicamba and 2,4,5-T applied alone were ineffective, whereas triclopyr at 60 or $120 \mathrm{~g} / \mathrm{L}$, picloram + dicamba, or picloram $+2,4,5-\mathrm{T}$ at $30+30 \mathrm{~g} / \mathrm{L}$ was intermediate in effect, killing about 40 to $55 \%$ of the plants. Rainfall was favorable before and after treatment (Table 2). These data agree with greenhouse investigations using a model carpeted roller that indicated that picloram, clopyralid, or mixtures of picloram + clopyralid were the most effective of several herbicides evaluated against juvenile huisache (Mayeux and Bovey 1988).

Fall applications of foliar sprays of picloram $+2,4,5-\mathrm{T}$ are some- 
Table 3. Response of hulache near Washington, Texas, to herbicides by 19 July 1984 after application by a carpeted roller on 20 October 1983.

\begin{tabular}{|c|c|c|c|}
\hline \multirow[b]{2}{*}{ Herbicide(s) } & \multirow[b]{2}{*}{ Rate } & \multicolumn{2}{|c|}{ Huisache control } \\
\hline & & $\begin{array}{l}\text { Canopy } \\
\text { reduction }\end{array}$ & $\begin{array}{c}\text { Dead } \\
\text { plants }\end{array}$ \\
\hline & (g/L a.e.) & $-(\%$ & \\
\hline Glyphosate & 60 & 19 & 5 \\
\hline Dicamba & 60 & 12 & 0 \\
\hline Dicamba & 120 & 30 & 0 \\
\hline Triclopyr & 60 & 56 & 40 \\
\hline Triclopyr & 120 & 71 & 50 \\
\hline $2,4,5-T$ & 60 & 36 & 18 \\
\hline Picloram & 60 & 82 & 75 \\
\hline Picloram & 120 & 86 & 82 \\
\hline Clopyralid & 60 & 97 & 92 \\
\hline Clopyralid & 120 & 92 & 88 \\
\hline Picloram + 2,4,5-T & $30+30$ & 58 & 42 \\
\hline Picloram + 2,4,5-T & $60+60$ & 86 & 85 \\
\hline Picloram + 2,4,5-T & $0.28+0.28 \mathrm{~kg} / \mathrm{ha}^{1}$ & 60 & 48 \\
\hline Picloram + 2,4,5-T & $0.56+0.56 \mathrm{~kg} / \mathrm{hal}$ & 90 & 82 \\
\hline Picloram + 2,4,5-T & $30 \div 30^{2}$ & 92 & 85 \\
\hline Picloram + clopyralid & $30+30$ & 96 & 95 \\
\hline Picloram + clopyralid & $60+60$ & 99 & 98 \\
\hline Picloram + clopyralid & $30+30^{3}$ & 93 & 90 \\
\hline Picloram + dicamba & $30+30$ & 68 & 55 \\
\hline Untreated & - - & 10 & 0 \\
\hline LSD (5\%) for column & & 27 & 30 \\
\hline
\end{tabular}

'Applied by hand boom sprayer.

21:4 ( $\mathrm{v} / \mathrm{v})$ diesel oil:water carrier.

${ }^{3}$ Treating solution contained $20 \mathrm{~g} / \mathrm{L}$ a.e. benazolin [4-chloro-2-oxo-3 $(2 \mathrm{H})$-benzo-thiazole acetic acid].

times more effective on huisache than spring or summer applications (Bovey et al. 1972). Also, foliar sprays of picloram at 2.2 $\mathrm{kg} / \mathrm{ha}$ or picloram $+2,4,5-\mathrm{T}$ at $1.1+1.1 \mathrm{~kg} / \mathrm{ha}$ is sometimes required to provide huisache mortality exceeding $80 \%$ (Bovey et al. 1970). In this study foliar sprays of $0.56+0.56 \mathrm{~kg} /$ ha of picloram + 2,4,5-T killed 47 and $3 \%$ huisache in 1985 and 1986 , respectively (Table 4). Picloram $+2,4,5-\mathrm{T}$ spray at $0.28+0.28 \mathrm{~kg} /$ ha was ineffective. Rainfall was limited 1 and 2 months after treatment in 1985 and 1 month before and after treatment in 1986. Reduced plant growth from drought probably reduced transport and activity of the foliar applied herbicides.

Application of clopyralid, picloram, picloram $+2,4,5-\mathrm{T}$, picloram + clopyralid or picloram + dicamba with the carpeted roller killed a high percentage of huisache plants in 1985 where adequate rainfall preceded treatment (Table 4). Picloram + clopyralid and picloram + dicamba were particularly effective, killing $95 \%$ or more of the huisache plants. Glyphosate, dicamba, triclopyr and $2,4,5-T$ reduced the canopy as much as $85 \%$ but killed only $35 \%$ or less of the plants. Treatments applied in 1986 generally killed fewer plants than in 1985 where rainfall was limited for a long period of time before and after treatment.

\section{Honey mesquite}

In actual field use, foliar sprays of picloram $+2,4,5-T$ have been applied at recommended rates of $0.28+0.28 \mathrm{~kg} / \mathrm{ha}$ to $0.56+0.56$ $\mathrm{kg} / \mathrm{ha}$ (Bovey and Meyer 1981). In this study, these herbicides caused 31 and $73 \%$ canopy reduction and killed 3 and $48 \%$ of the plants, respectively, by 2 years after treatment (Table 5). Mortality of honey mesquite was about as expected for foliar sprays of picloram $+2,4,5-\mathrm{T}$ at these rates in east Texas. Canopy reduction and mortality of picloram $+2,4,5-\mathrm{T}$ applied by the carpeted roller were similar to foliar sprays. Picloram $+2,4,5-\mathrm{T}$ at $30+30 \mathrm{~g} / \mathrm{L}$ applied in a 1:4 ( $\mathrm{v} / \mathrm{v})$ diesel oil:water carrier appeared superior to water carrier alone after 1 year but was no different by the second year (1985) after application. Carpeted wiper treatments that killed $78 \%$ or more of the plants included picloram at $120 \mathrm{~g} / \mathrm{L}$, clopyralid 13 May 1986 and 5 May 1987 after application by a carpeted roller on 15 July 1985 and 14 July 1986, respectively.

\begin{tabular}{|c|c|c|c|c|c|}
\hline \multirow[b]{3}{*}{ Herbicide(s) } & \multirow[b]{3}{*}{ Rate } & \multicolumn{4}{|c|}{ Date applied } \\
\hline & & \multicolumn{2}{|c|}{15 July 1985} & \multicolumn{2}{|c|}{14 July 1986} \\
\hline & & $\begin{array}{l}\text { Canopy } \\
\text { reduction }\end{array}$ & $\begin{array}{c}\text { Dead } \\
\text { plants }\end{array}$ & $\begin{array}{l}\text { Canopy } \\
\text { reduction }\end{array}$ & $\begin{array}{l}\text { Dead } \\
\text { plants }\end{array}$ \\
\hline \multirow[b]{2}{*}{ Glyphosate } & \multirow{2}{*}{$\begin{array}{c}\text { (g/L a.e.) } \\
60\end{array}$} & \multicolumn{4}{|c|}{$-(\%)$} \\
\hline & & 58 & 10 & 57 & 13 \\
\hline Dicamba & 60 & 78 & 20 & 67 & 15 \\
\hline Dicamba & 120 & 80 & 23 & 80 & 20 \\
\hline Triclopyr & 60 & 64 & 5 & 63 & 13 \\
\hline Triclopyr & 120 & 76 & 33 & 78 & 25 \\
\hline $2,4,5-T$ & 60 & 85 & 35 & 67 & 10 \\
\hline Picloram & 60 & 96 & 88 & 97 & 85 \\
\hline Picloram & 120 & 97 & 93 & 89 & 68 \\
\hline Clopyralid & 60 & 93 & 85 & 65 & 20 \\
\hline Clopyralid & 120 & 90 & 88 & 99 & 90 \\
\hline$\underset{2,4,5-T}{\text { Picloram }}+$ & $30+30$ & 96 & 70 & 89 & 63 \\
\hline $\begin{array}{c}\text { Picloram + } \\
2,4,5-\mathrm{T}\end{array}$ & $60+60$ & 98 & 83 & 96 & 73 \\
\hline $\begin{array}{c}\text { Picloram + } \\
2,4,5-T\end{array}$ & $\begin{array}{c}0.28+0.28 \\
\mathrm{~kg} / \mathrm{hal}^{\mathrm{l}}\end{array}$ & 62 & 5 & 29 & 0 \\
\hline $\begin{array}{c}\text { Picloram + } \\
2,4,5-T\end{array}$ & $\begin{array}{c}0.56+0.56 \\
\mathrm{~kg} / \mathrm{ha}^{1}\end{array}$ & 70 & 47 & 37 & 3 \\
\hline $\begin{array}{c}\text { Picloram + } \\
2,4,5-T\end{array}$ & $30+30^{2}$ & 94 & 85 & 91 & 70 \\
\hline $\begin{array}{l}\text { Picloram + } \\
\text { clopyralid }\end{array}$ & $30+30$ & 100 & 98 & 89 & 60 \\
\hline $\begin{array}{c}\text { Picloram }+ \\
\text { clopyalid }\end{array}$ & $60+60$ & 100 & 98 & 97 & 80 \\
\hline $\begin{array}{l}\text { Picloram + } \\
\text { clopyralid }\end{array}$ & $30+30^{3}$ & 100 & 98 & 92 & 58 \\
\hline $\begin{array}{r}\text { Picloram + } \\
\text { dicamba }\end{array}$ & $30+30$ & 94 & 95 & 80 & 38 \\
\hline Untreated & -- & 2 & $\mathbf{0}$ & 6 & 0 \\
\hline LSD $(5 \%$ & r column & 14 & 15 & 14 & 22 \\
\hline
\end{tabular}

'Applied by hand boom sprayer.

$21: 4(v / v)$ diescl oil: water carrier.

3Treating solution contained $20 \mathrm{~g} / \mathrm{L}$ a.e. benazolin [4-chloro-2-oxo-3(2H)-benzothiazole acetic acidl.

at 60 and $120 \mathrm{~g} / \mathrm{L}$, and picloram + clopyralid at $60+60 \mathrm{~g} / \mathrm{L}$. Picloram + clopyralid at $30+30 \mathrm{~g} / \mathrm{L}+20 \mathrm{~g} / \mathrm{L}$ benazolin killed $80 \%$ of the honey mesquite but was no different than the same treatment without benazolin. All of these carpeted roller treatments were superior to foliar sprays of picloram $+2,4,5-\mathrm{T}$. Glyphosate, dicamba, triclopyr and 2,4,5-T applied by the carpeted roller killed only $15 \%$ or less of the plants. Canopy reduction and mortality evaluations were similar whether taken 1 or 2 years after treatment although some treatments showed more regrowth by the second year.

Foliar sprays of picloram $+2,4,5-\mathrm{T}$ were ineffective in killing honey mesquite by 1 or 2 years after spraying when applied in June 1984 (Table 6). The reasons for poor results is not clear; timing of treatment and rainfall amounts (Table 2) were satisfactory. Canopy reduction and mortality from picloram $+2,4,5-\mathrm{T}$ applied by carpeted roller were superior to foliar sprays of picloram + 2,4,5-T as were picloram, clopyralid or mixtures of picloram + clopyalid. Picloram + clopyralid at $60+60 \mathrm{~g} / \mathrm{L}$ killed $98 \%$ of the plants. Clopyralid + triclopyr at $30+30$ or $60+60 \mathrm{~g} / \mathrm{L}$ killed 58 and $80 \%$ of the plants after 2 years, respectively. Sprays of clopyralid + picloram or clopyralid + triclopyr are highly effective on honey mesquite at $0.28+0.28 \mathrm{~kg} / \mathrm{ha}$ and $0.56+0.56 \mathrm{~kg} / \mathrm{ha}$ (Bovey and Meyer 1985 ). In this study, picloram + dicamba at $30+30$ or $60+60 \mathrm{~g} / \mathrm{L}$ killed about the same percentage of plants as picloram alone at $60 \mathrm{~g} / \mathrm{L}(35$ to $60 \%$ ). Glyphosate, dicamba, triclopyr and $2,4,5-\mathrm{T}$ killed 
Table 5. Response of honey mesquite near Bryan, Texas, to herbicides by 7 Auguat 1984 and 6 August 1985 after application by a carpeted roller on 6 July 1983.

\begin{tabular}{|c|c|c|c|c|c|}
\hline \multirow[b]{3}{*}{ Herbicide(s) } & \multirow[b]{3}{*}{ Rate } & \multicolumn{4}{|c|}{ Date evaluated } \\
\hline & & \multicolumn{2}{|c|}{1984} & \multicolumn{2}{|c|}{1985} \\
\hline & & $\begin{array}{c}\text { Canopy } \\
\text { reduction }\end{array}$ & $\begin{array}{l}\text { Dead } \\
\text { plants }\end{array}$ & $\begin{array}{c}\text { Canopy } \\
\text { reduction }\end{array}$ & $\begin{array}{l}\text { Dead } \\
\text { plants }\end{array}$ \\
\hline & (g/L a.e.) & & & & \\
\hline Glyphosate & 60 & 38 & 5 & 22 & 0 \\
\hline Glyphosate & 120 & 55 & 8 & 30 & 3 \\
\hline Dicamba & 60 & 48 & 3 & 30 & 5 \\
\hline Dicamba & 120 & 71 & 10 & 30 & 8 \\
\hline Triclopyr & 60 & 53 & 5 & 24 & 0 \\
\hline Triclopyr & 120 & 65 & 3 & 25 & 0 \\
\hline $2,4,5-T$ & 60 & 58 & 15 & 39 & 10 \\
\hline $2,4,5-\mathrm{T}$ & 120 & 63 & 0 & 36 & 0 \\
\hline Picloram & 60 & 75 & 43 & 66 & 40 \\
\hline Picloram & 120 & 97 & 83 & 93 & 78 \\
\hline Clopyralid & 60 & 99 & 95 & 99 & 98 \\
\hline Clopyralid & 120 & 98 & 80 & 90 & 78 \\
\hline $\begin{array}{c}\text { Picloram + } \\
2,4,5-T\end{array}$ & $30+30$ & 84 & 30 & 58 & 23 \\
\hline $\begin{array}{c}\text { Picloram + } \\
2,4,5-T\end{array}$ & $60+60$ & 89 & 50 & 68 & 35 \\
\hline $\begin{array}{c}\text { Picloram + } \\
2,4,5-T\end{array}$ & $\begin{array}{c}0.28+0.28 \\
\mathrm{~kg} / \mathrm{ha}^{1}\end{array}$ & 68 & 20 & 31 & 3 \\
\hline $\begin{array}{c}\text { Picloram + } \\
2,4,5-T\end{array}$ & $\begin{array}{c}0.56+0.56 \\
\mathrm{~kg} / \mathrm{ha}^{1}\end{array}$ & 88 & 40 & 73 & 48 \\
\hline $\begin{array}{c}\text { Picloram + } \\
2,4,5-T\end{array}$ & $30+30^{2}$ & 94 & 78 & 69 & 45 \\
\hline $\begin{array}{l}\text { Picloram + } \\
\text { clopyralid }\end{array}$ & $30+30$ & 96 & 73 & 87 & 73 \\
\hline $\begin{array}{c}\text { Picloram + } \\
\text { clopyralid }\end{array}$ & $60+60$ & 98 & 85 & 90 & 83 \\
\hline $\begin{array}{c}\text { Picloram + } \\
\text { clopyralid }\end{array}$ & $30+30^{3}$ & 98 & 83 & 94 & 80 \\
\hline $\begin{array}{l}\text { Untreated } \\
\text { LSD (5\%) }\end{array}$ & $\overline{\text { column }}$ & $\begin{array}{r}3 \\
14\end{array}$ & $\begin{array}{r}0 \\
24\end{array}$ & $\begin{array}{r}2 \\
20\end{array}$ & $\begin{array}{r}0 \\
24\end{array}$ \\
\hline
\end{tabular}

'Applied by hand boom sprayer.

$21: 4(\mathrm{v} / \mathrm{v})$ diesel oil:water carrier.

${ }^{3}$ Treating solution contained $20 \mathrm{~g} / \mathrm{L}$ a.e. benazolin [4-chloro-2-oxo-3(2H)-benzothiazole acetic acid].

$35 \%$ of the plants or less by 2 years after treatment.

Carpeted roller treatments of picloram, clopyralid, picloram + clopyralid, picloram + dicamba and clopyralid + triclopyr were superior to foliar sprays of picloram $+2,4,5-\mathrm{T}$ (Table 7). Carpeted roller treatments of picloram $+2,4,5-\mathrm{T}$ at $60+60 \mathrm{~g} / \mathrm{L}$ killed more honey mesquite than foliar sprays of picloram $+2,4,5-T$. Picloram $+2,4,5-\mathrm{T}$ at $30+30 \mathrm{~g} / \mathrm{L}$ also killed more plants thay sprays of picloram $+2,4,5-\mathrm{T}$ at $0.28+0.28 \mathrm{~kg} / \mathrm{ha}$. Treatments that killed over $80 \%$ of the plants included clopyralid at $60 \mathrm{~g} / \mathrm{L}$, picloram + clopyralid at $60+60 \mathrm{~g} / \mathrm{L}$, picloram + clopyralid + benazolin at $30+30$ $+20 \mathrm{~g} / \mathrm{L}$, respectively, and clopyralid + triclopyr at $60+60 \mathrm{~g} / \mathrm{L}$. Ineffective treatments were glyphosate, dicamba, triclopyr and 2,4,5-T. Honey mesquite mortality from foliar sprays of picloram + 2,4,5-T was within the expected range (Bovey and Meyer 1981). Rainfall amounts were low 1 month before treatment (Table 2).

Mayeux (1987b) indicated that rates of application of herbicide applied to honey mesquite with the carpeted roller at concentrations of 30,60 , and $120 \mathrm{~g} / \mathrm{L}$ averaged about $0.2,0.6$, and $1.25 \mathrm{~kg}$ a.e./ha. Based on this criterion, foliar sprays of picloram $+2,4,5-\mathrm{T}$ at $0.28+0.28$ and $0.56+0.56 \mathrm{~kg} / \mathrm{ha}$ for a total of 0.56 and $1.1 \mathrm{~kg} / \mathrm{ha}$ would be comparable to 60 and $120 \mathrm{~g} / \mathrm{L}$ applied by the carpeted roller on a herbicide/ha basis. Amount of herbicide used and cost/ ha should be comparable. The carpeted roller treatments, however, were usually more effective than the herbicide sprays on
Table 6. Response of honey mesquite near Bryan, Texas, to herbicides by 6 Auguat 1985 and 25 June 1986 after application by a carpeted roller on 15 June 1984.

\begin{tabular}{|c|c|c|c|c|c|}
\hline \multirow[b]{3}{*}{ Herbicide(s) } & \multirow[b]{3}{*}{ Rate } & \multicolumn{4}{|c|}{ Date applied } \\
\hline & & \multicolumn{2}{|c|}{1985} & \multicolumn{2}{|c|}{1986} \\
\hline & & $\begin{array}{l}\text { Canopy } \\
\text { reduction }\end{array}$ & $\begin{array}{c}\text { Dead } \\
\text { plants }\end{array}$ & $\begin{array}{l}\text { Canopy } \\
\text { reduction }\end{array}$ & $\begin{array}{l}\text { Dead } \\
\text { plants }\end{array}$ \\
\hline \multirow[b]{2}{*}{ Glyphosate } & (g/L a.e.) & \multicolumn{4}{|c|}{ (\%) } \\
\hline & 60 & 55 & 8 & 33 & 5 \\
\hline Glyphosate & 120 & 77 & 35 & 35 & 8 \\
\hline Dicamba & 60 & 61 & 15 & 61 & 35 \\
\hline Dicamba & 120 & 86 & 43 & 46 & 13 \\
\hline Triclopyr & 60 & 78 & 10 & 47 & 5 \\
\hline Triclopyr & 120 & 95 & 60 & 67 & 33 \\
\hline $2,4,5-T$ & 60 & 65 & 5 & 50 & 18 \\
\hline $2,4,5-T$ & 120 & 85 & 40 & 55 & 10 \\
\hline Picloram & 60 & 90 & 60 & 71 & 43 \\
\hline Picloram & 120 & 98 & 93 & 93 & 83 \\
\hline Clopyralid & 60 & 92 & 78 & 81 & 65 \\
\hline Clopyralid & 120 & 99 & 90 & 91 & 83 \\
\hline$\underset{2,4,5-T}{\text { Picloram }}+$ & $30+30$ & 87 & 60 & 66 & 43 \\
\hline $\begin{array}{c}\text { Picloram + } \\
2,4,5-\mathrm{T}\end{array}$ & $60+60$ & 97 & 80 & 80 & 53 \\
\hline $\begin{array}{c}\text { Picloram + } \\
\text { 2,4,5-T }\end{array}$ & $\begin{array}{c}0.28+0.28 \\
\mathrm{~kg} / \mathrm{ha}^{1}\end{array}$ & 53 & 3 & 30 & 3 \\
\hline $\begin{array}{r}\text { Piclorm + } \\
2,4,5-T\end{array}$ & $\begin{array}{c}0.56+0.56 \\
\mathrm{~kg} / \mathrm{ha}^{1}\end{array}$ & 64 & 3 & 35 & 8 \\
\hline$\underset{2,4,5-T}{\text { Picloram }}+$ & $30+30^{2}$ & 88 & 55 & 76 & 50 \\
\hline $\begin{array}{l}\text { Picloram + } \\
\text { clopyralid }\end{array}$ & $30+30$ & 96 & 83 & 97 & 58 \\
\hline $\begin{array}{l}\text { Picloram + } \\
\text { clopyralid }\end{array}$ & $60+60$ & 100 & 100 & 99 & 98 \\
\hline $\begin{array}{l}\text { Picloram + } \\
\text { clopyralid }\end{array}$ & $30+30^{3}$ & 97 & 88 & 83 & 63 \\
\hline $\begin{array}{c}\text { Picloram + } \\
\text { dicamba }\end{array}$ & $30+30$ & 88 & 60 & 64 & 35 \\
\hline $\begin{array}{r}\text { Picloram + } \\
\text { dicamba }\end{array}$ & $60+60$ & 89 & 60 & 71 & 50 \\
\hline$\underset{\text { triclopyr }}{\text { Clopyralid + }}$ & $30+30$ & 96 & 75 & 83 & 58 \\
\hline $\begin{array}{c}\text { Clopyralid + } \\
\text { triclopyr }\end{array}$ & $60+60$ & 95 & 73 & 93 & 80 \\
\hline Untreated & - & 4 & 0 & 4 & 0 \\
\hline $\operatorname{LSD}(5 \%$ & $r$ column & 9 & 17 & 18 & 26 \\
\hline
\end{tabular}

IApplied by hand boom sprayer.

21:4 (v/v) diesel oil:water carrier.

${ }^{3}$ Treating solution contained $20 \mathrm{~g} / \mathrm{L}$ a.e. benazolin [4-chloro-2-oxo-3(2H)-benzothiazole acetic acid].

both huisache and honey mesquite. This is probably due to a greater concentration of herbicide being applied to each plant by the carpeted roller.

These studies demonstrate that picloram or clopyralid at rates of 60 or $120 \mathrm{~g} / \mathrm{L}$ or $1: 1$ mixtures of picloram + clopyralid or picloram $+2,4,5-T$ applied by the carpet roller are highly effective for reducing the canopy and causing high mortality of huisache from summer and fall treatments. Picloram $+2,4,5-T$ applied by the carpeted roller was sometimes more effective than sprays of the same mixture. Picloram, clopyralid, or 1:1 mixtures either of picloram + clopyralid or clopyralid + triclopyr were most effective for control honey mesquite applied in June or July. Small, dense, $1<2$ $m$ tall) honey mesquite and/or huisache and associated weeds can be controlled using the carpeted roller near sensitive crops and domestic areas, thus minimizing herbicide residues to non-target, hay or grazing areas before the species become too large and unmanageable. 
Table 7. Response of honey mesquite near Bryan, Texas, to herbicides by 23 June 1986 after application by a carpeted roller on 12 June 1985.

\begin{tabular}{|c|c|c|c|}
\hline \multirow[b]{2}{*}{ Herbicide(s) } & \multirow[b]{2}{*}{ Rate } & \multicolumn{2}{|c|}{$\begin{array}{l}\text { Honey mesquite } \\
\text { control }\end{array}$} \\
\hline & & $\begin{array}{l}\text { Canopy } \\
\text { reduction }\end{array}$ & $\begin{array}{l}\text { Dead } \\
\text { plants }\end{array}$ \\
\hline & (g/L a.e.) & \multicolumn{2}{|c|}{$-(\%)-(\%$} \\
\hline Glyphosate & 60 & 52 & 13 \\
\hline Glyphosate & 120 & 51 & 5 \\
\hline Dicamba & 60 & 52 & 3 \\
\hline Dicamba & 120 & 57 & 10 \\
\hline Triclopyr & 60 & 42 & 0 \\
\hline Triclopyr & 120 & 68 & 13 \\
\hline $2,4,5-T$ & 60 & 74 & 10 \\
\hline $2,4,5-\mathrm{T}$ & 120 & 57 & 3 \\
\hline Picloram & 60 & 75 & 40 \\
\hline Picloram & 120 & 93 & 63 \\
\hline Clopyralid & 60 & 95 & 83 \\
\hline Picloram $+2,4,5-T$ & $30+30$ & 72 & 28 \\
\hline Picloram $+2,4,5-T$ & $60+60$ & 85 & 48 \\
\hline Picloram + 2,4,5-T & $0.28+0.28 \mathrm{~kg} / \mathrm{hal}^{\mathrm{l}}$ & 24 & 3 \\
\hline Picloram + 2,4,5-T & $0.56+0.56 \mathrm{~kg} / \mathrm{hal}^{\mathrm{l}}$ & 65 & 23 \\
\hline Picloram + 2,4,5-T & $30+30^{2}$ & 68 & 10 \\
\hline Picloram + clopyralid & $30+30$ & 93 & 73 \\
\hline Picloram + clopyralid & $60+60$ & 98 & 90 \\
\hline Picloram + clopyralid & $30+30^{3}$ & 96 & 88 \\
\hline Picloram + dicamba & $30+30$ & 84 & 48 \\
\hline Picloram + dicamba & $30+30$ & 87 & 60 \\
\hline Clopyralid + triclopyr & $30+30$ & 86 & 48 \\
\hline Clopyralid + triclopyr & $60+60$ & 98 & 85 \\
\hline Untreated & - - & 6 & 0 \\
\hline LSD ( $5 \%)$ for column & & 12 & 16 \\
\hline
\end{tabular}

'Applied by hand boom sprayer.

$21: 4(v / v)$ diesel oil:water carrier.

${ }^{3}$ Treating solution contained $20 \mathrm{~g} / \mathrm{L}$ a.e. benazolin [4-chloro-2-oxo-3(2H)-benzothiazole acetic acid] and $1 \%$ (v/v) surfactant (trimethyl nonylpoly ethoxyethanol).

\section{Literature Cited}

Bovey, R.W., J.R. Baur, and H.L. Morton. 1970. Control of huisache and associated woody species in south Texas. J. Range Manage. 20:577-580.

Bovey, R.W., R.H. Haas, and R.E. Meyer. 1972. Daily and seasonal response of huisache and Macartney rose to herbicides. Weed Sci. 20:577-580.

Bovey, R.W., and R.E. Meyer. 1978. Control of huisache with soil applied herbicides. J. Range Manage. 31:179-182.

Bovey, R.W., and R.D. Meyer. 1981. The response of honey mesquite to herbicides. Texas Agr. Exp. Sta. B-1363.

Bovey, R.W., R.E. Meyer, and J.R. Baur. 1981. Potential herbicides for brush control. J. Range Manage. 34:144-148.

Bovey, R.W., and R.E. Meyer. 1985. Herbicide mixtures for control of honey mesquite (Prosopis glandulosa). Weed Sci. 33:349-352.

Mayeux, H.S., Jr., and R.A. Crane. 1984. Application of herbicides on rangeland with a carpeted roller: Control of goldenweeds (Isocoma spp.) and false broomweed (Ericamera austrotexana). Weed Sci. 32:845-849.

Mayeux, H.S., Jr., and R.A. Crane. 1985. Applications of herbicides on rangelands with a carpeted roller: Evaluation of four herbicides for control of honey mesquite. J. Range Manage. 38:238-241.

Mayeux, H.S., Jr. 1987a. Applications of herbicides on rangelands with a carpeted roller: Timing of treatment in dense stands of honey mesquite. J. Range Manage. 40:348-352.

Mayeux, H.S., Jr. 1987b. Application of herbicides on rangelands with a carpeted roller: Shrub density influences volume, dosage, and rate. Weed Sci. 35:444-448.

Mayeux, H.S., Jr., and R.W. Bovey. 1988. Effectiveness of herbicides applied with a model carpeted roller to huisache (Acacia farnesiana) seedlings in the glasshouse. Weed Technol. 3:232-237.

Scifres, C.J. R.A. Crane, B.H. Koerth, and R.C. Flinn. 1988. Roller application of clopyralid for huisache (Acacia farnesiana) control. Weed Technol. 2:317-322.

Steel, R.G.D., and J.H. Torrie. 1980. Principles and procedures of statistics. A biometrical approach. McGraw-Hill Book Co., New York.

Waddington, J., and S. Bittman. 1987. Effect of number of passes with a roller-applicator using dilute herbicide solutions on control of brush regrowth in northeastern Saskatchewan. Can. J. Plant Sci. 67:845-848.

\section{Notice to Authors}

A FORM TO BE USED WHEN SUBMITTING MANUSCRIPTS is published on the last two pages of the Journal. A copy of this form must accompany all manuscripts submitted after July 1, 1989. 